\title{
Political Legitimacy, Democracy and Islamic Law: The Place of Self-Government in Islamic Political Thought
}

\author{
Mohammad Fadel \\ Professor of Law at the University of Toronto Faculty of Law \\ mohammad.fadel@utoronto.ca
}

\begin{abstract}
Contemporary Political Islam, or Islamism, is commonly defined as a movement that seeks to apply the Sharīa as the basic law of Muslim states. This suggests that political legitimacy in Islamic thought can be reduced to the conformity of a polity's actions to a pre-determined body of rules that are supplied by revelation, as supplemented by the interpretations of jurists. Such a demand is reasonably understood to be non-democratic because it includes no room for self-government by making it either redundant, if it produces results that are in conformity with the norms of the Sharīa, or contradictory to self-government, if the results of self-government differ from revealed norms. I argue instead that Islamic constitutional theory and political thought provide explicit grounds for self-government based on a conception of the state that is grounded in the ideals of agency and fiduciary duties rather than conformity with the pre-determined substantive norms of revelation simpliciter. On this account, self-government is essential to political legitimacy because the legitimacy of the ruler's decisions can only be understood from the perspective of whether the people, as the principal who authorized the agent (i.e., the government), approves of the government's conduct, or can reasonably be understood to approve of the government's conduct. This has important implications for understanding how a state can, consistent with self-government, incorporate the Sharīa and its values in its legislative system. Far from imposing particular outcomes, in most cases, the rules of the Sharía will only present options for how public law may be made, while giving the public the freedom, through the exercise of its collective deliberation, to choose how it operationalizes various provisions and values of the Sharīa in positive law in relation to its own determination of its own rational good (mașlaha).
\end{abstract}




\section{Keywords}

Islam - Sharī‘a - Islamic political theory - political legitimacy - constitutionalism self-government - social contract - agency - fiduciary duties - positive law - public good - democracy

Did pre-modern Sunnī jurists and theologians have a theory of political legitimacy, or were their political writings merely post hoc justifications of the status quo? The prevailing scholarly wisdom is that Sunnī political thought suggests the latter. (See Fadel 2014, 93-107). In my view, however, the conventional wisdom is erroneous because Sunnī jurists and theologians never sought to justify the status quo, if we understand that to mean that they used their status as intellectuals to accord de jure legitimacy to whoever held power. It is also poor intellectual history insofar as a major work of that tradition, such as that of al-Māwardì's al-Aḥkām al-Sulțāniyya, can hardly be understood to be a justification of the status quo of the Islamic world of the fifth hijrī century. Rather, if we read that work against the background of the realities of the 'Abbāsid state at that time, we could only conclude that al-Māwardì's work was revolutionary, at least to the extent that its implementation would have radically transformed the politics of his age.

A more accurate perspective on the legacy of Sunnì political thought would be that certain historical precedents functioned as fixed-points of reference for determining political legitimacy, such as the legitimacy of first four caliphs, the sinfulness of 'Uthmān's assassins and those who aided and abetted them, and the probity ('adāla) of the companions. This meant that the senior companions of the Prophet, despite the fact that they fought against 'Alī, the legitimate caliph in the eyes of the later Sunnì tradition, on The Day of the Camel, and at Șiffin, could not be condemned as sinners, much less deemed apostates. Rather, Sunnīs excused them because they were deemed to have fought him not for illicit worldly motives, e.g., a naked desire for power, but out of a sincere, but mistaken $\left(t a^{\prime}\right.$ wĭl) understanding of Islamic law. A more faithful reading of Sunnì political theory requires the scholar to be sensitive both to the author's normative historical commitments, and his prospective normative program, as well as the practical circumstances which constrain the author at any given time, circumstances which both generate some possibilities for political reform while foreclosing others.

This dialectical relationship between aspiration and possibility is obvious in the writings of Sunnī Islam's best pre-modern theorists, such as Ibn Khaldūn, 
but it also left its traces in the sundry writings of Sunnī jurists as they explicated the rules that apply to public officials, and how their decisions affect the obligations of ordinary citizens, to say nothing of the major works of a figure such as al-Māwardī. This essay proceeds in two parts. I will argue in the first part that the central legitimating idea of pre-modern Sunni political thought was that the ruler, and all lesser public officials a fortiori, exercised their authority exclusively pursuant to delegations from the Muslim community writ large, and as such, were merely their agents in the pursuit of Muslim community's common good. (See Fadel 2017, 44-90). The metaphor of agency, although it limited the authority of public officials, also empowered them to make morally binding rules in furtherance of the common good, and if need be, compel individual members of the community, to follow those rules, even in circumstances where revelation could not reasonably be read as imposing such obligations.

The second part of this paper explores the practical political implications that flow from this notion of political legitimacy. It argues that electoral democracy, in current circumstances, represents the most practical means to make effective the Sunnì ideal of self-government under the ideals of divine law. It then offers a brief conclusion.

\section{Sunnī Political Theology and the Legitimacy of Self-Government}

The death of the Prophet Muhammad forced the Muslim community to make far reaching decisions about the nature of the Muslim community after the Prophet's death. The first question was whether the community the Prophet had founded would continue in existence after his death. The wars of apostasy can be understood to have resolved conclusively the first question in the affirmative: the Muslim community would survive despite the death of the Prophet, and that the community had the power, indeed, the responsibility, to coerce those who sought to secede from the community to compel them to return to the fold. ${ }^{1}$ But these wars did not resolve the question of post-Prophetic leadership, and its relationship to the divine.

1 The wars of apostacy, with a few prominent exceptions (most notably, the Banū Hanīfa), did not involve actual apostasy. The majority of the combatants continued to adhere to Islam, but refused, initially at least, to submit to the political authority of Abū Bakr as the leader of the Muslim community in the wake of the Prophet's death. 
The essential question that divided the community was the characteristics of the community's legitimate leader in the post-Prophetic era. One group of Muslims insisted that legitimate leadership required the possession of special, charismatic authority that radically distinguished the leader from all other members of the community. These became what we now call today the Shía. Those Muslims who rejected a charismatic basis to leadership were in turn divided with respect to the degree of excellence ( $f a d l)$ that a legitimate leader was required to possess. The majority of this second group of Muslims eventually came to be called the ahl al-sunna wa'-jamäa, i.e., the Sunnīs, while the minority of this group, even though they agreed with the Sunniss regarding the ordinary humanity of the community's leaders, disagreed with the Sunniss regarding the qualifications of a legitimate leader. This third group came to be known as the Khawārij, "the secessionists."

Sunnīs agreed that a legitimate ruler must possess virtue ( fädil), but he need not be the most virtuous (afdal) member of the community. All that was required according to the Sunnīs was that the ruler meet the less demanding standard of probity ('adāla). (See Ziadeh 1994, 73-93). The Khawārij, on the other hand, insisted that the ruler need to be the most virtuous member of the community. For them, the leader of the Muslim community must not only be the most virtuous member of the Muslim community at the time of his selection, he could forfeit his legitimacy by subsequently engaging in sinful conduct. In that case, the Muslim community was obligated to depose him and replace him with a worthier candidate. (See Geiser 2010; Crone 2005, chap. 5). Their claim that leadership was only legitimate if it was exercised by the most virtuous of the Muslim community was similar to that of the Shi'a insofar as both groups made the personal excellence-indeed perfection-of the ruler to be the sine qua non of legitimate leadership.

The political theology of Sunnism rejected both the perfectionism of both the Shī'a and of the Khawārij. Sunnis' theological position was buttressed by numerous assumptions about the nature of revelation, and its universal accessibility to anyone possessed of ordinary human intelligence with knowledge of the Arabic language. (See, for example, Weiss 1990, 53-71). It was also reflected in various Sunnì theological doctrines, such as the notion that faith increases and decreases, and the major sinner, despite his sins, remains a member of the Muslim community, in this life and the next. (See Yusuf 2007, 64-68). The Sunnīs' toleration of the individual sinner extended to the community's political order, which could be legitimate even if it was imperfect, just as an individual Muslim remained a member in good standing of the community despite his sins. (See Yusuf 2007, 70). A fortiori, Sunnīs affirmed the fundamental 
probity of the earliest Muslim community, the Prophet's closest companions, and his wives. (See Yusuf 2007, 76).

Sunnīs were able to take this theologically tolerant and inclusive position because of their belief that the unity and continuity of the community was a result of its common adherence to the rules of Islamic law. Sunnī tolerance was not licentiousness, however, for it assumed that all Muslims would be accountable for their actions, either in this world, before the courts of an Islamic state, or in the next life, before God. Political life was crucial, not for itself, but rather because it was an indispensable condition that enabled the community to live out its moral ideals. In other words, for the Sunnis, the necessity of the state was that it provided the only realistic means for the achievement of the ends that Islam imposed on Muslims, collectively and individually, but it was not demanded for its own sake, in contrast to the obligation, for example, to establish regular prayer. (See al-Ghazālī 1986, 28-29).

The egalitarian and inclusive theological positions of Sunnism, however, generated certain problems for the legitimacy of political ordering. If all persons were substantially equal, morally and intellectually, Sunnī religious doctrine could not provide an obvious answer to the question of who should assume the mantle of political leadership. When combined with the assumption that even persons of ordinary integrity were fit for leadership, Sunni theology contained the seeds for a radically subversive political theology. Indeed, the 12th century Muslim theologian al-'Izz b. 'Abd al-Salām succinctly articulated the political consequences of Sunni theological doctrines by stating that "no human is more worthy of obedience than another" and that it is only God who is entitled to an unqualified duty of obedience. (Ibn 'Abd al-Salām n.d., 2:157). For al-'Izz the willingness of human beings to obey other human beings also entailed a profound theological error: the false belief that one human being could be the effective cause of benefit or harm to another human being to the exclusion of God. Because Islam teaches that God is the only effective cause of benefit and harm, a Muslim should never obey another because that other person, for example, has superior force. Obedience, therefore, is only consistent with human equality and dignity to the extent that God has authorized a duty of obedience to another.

Ibn 'Abd al-Salam recognized that God did indeed authorize obedience to others in the context of particular bilateral relationships in the household, such as the duty of children to obey their parents, of a wife to obey her husband, and of a slave to obey his master, and in the marketplace, such as the duty of an employee to obey his employer. He also affirmed in principle the obligation to obey public officials, those whom he called "the Imams, judges 
and governors." But he also called into question that very principle by excluding from that duty obedience to "ignorant kings and princes." In such cases, obedience can only arise if "the recipient of the command ascertains that revelation permits the command." (Ibn 'Abd al-Salām n.d., 2:157). In other words, it is only legitimate Imams, judges and rulers who are morally entitled to obedience. Illegitimate rulers, by contrast, may have power, but they lack authority, and accordingly, no moral duty of political obedience existed with respect to them. If a moral duty of obedience arose in such cases, it was only because the subject has ascertained independently that the command may be followed without the risk of disobeying God. As a matter of principle, however, sinful commands can never produce a moral duty of obedience, as that would contradict God's sovereignty.

Ibn 'Abd al-Salām's brief discussion of the obedience as a moral concept succinctly sums up the consequences of Sunnī conceptions of political legitimacy: obedience is only due a legitimate ruler, and a ruler's commands are legitimate only to the extent that they do not contravene Islamic law. His discussion of legitimacy centers around two issues. The first is whether the person issuing the command is authorized to command others, i.e., is an Imām, judge or ruler. The second is whether the command itself is substantively legitimate, a question which is determined by comparing the substance of the command with the contents of divine law.

The jurisdictional question, viz., how are we to know whether a person who purports to command us is in fact a legitimate Imām, judge or ruler, and therefore entitled to our obedience, or if he is just an ordinary person, or even worse, a thug, and accordingly, is owed no duty of obedience, therefore became a matter of urgency for Sunni thinkers. It is the function of the Sunni theory of the caliphate to answer this question.

Modern scholarship, unfortunately, has largely been dismissive of Sunnī writings on the caliphate. I believe, however, that a careful reading of the rules of the caliphate allows one to discover the most salient political ideals of Sunnīs. When this approach is taken to a text like al-Māwardī's al-Ahkām al-Sultanniyya, the centrality of contract to its idea of legitimacy is inescapable. While this is no secret to students of Sunnī political thought, modern scholarship has focused almost excessively on the empirical question of whether the practice of Muslim polities actually reflected al-Māwardì's views rather than the normative entailments of this conception of legitimacy in Sunnī legal thought. It is at least as important, however, to determine the extent to which the idea of contract animates Sunnī law's approach to the problem of governance generally, and to the extent possible, determine what the ideal content of that contract was. 
Reading al-Ahkām al-Sulțāniyya normatively results in the following conclusions. First, creation of the political order is a collective obligation (fard kifāya), and no individual Muslim may decline to accept his role in that community. (al-Māwardī n.d., 17). ${ }^{2}$ Those who refuse to accept the legitimacy of the political order, at least in certain circumstances, can be legitimately fought as rebels (ahl al-baghy) and coerced into obedience. (al-Māwardī n.d., 74).

Second, although recalcitrant parties may be coerced into the contract, the contract's terms must be reasonably beneficial to all the contracting parties. This feature of the contract is reflected in several features of its provisions. For example, the electors, ahl al-hall wa'-'aqd, do not act in a personal capacity, but rather are expressly charged with acting in a representative capacity on behalf of the entire Muslim community. They are therefore bound to exercise their power of selection to choose the best reasonably available candidate for the job. In discharging this duty, they are to consider a mix of factors, including, moral character, bravery, learning, descent from Quraysh, and political competence, weighing these different factors in light of the candidates reasonably available, and in light of the present needs of the community. Later jurists, however, were willing to dispense with the requirement that the candidate be of Quraysh provided the other qualifications were satisfied. (al-Shirbinī 1994, $5: 422-423$ ). This same duty applies to the sitting caliph if he acts in the capacity of an elector by appointing his successor, wali al- $a$ ahd. ${ }^{3}$ Once the electors discharge this duty, moreover, they cannot reconvene to depose the caliph at their will. Likewise, the incumbent caliph cannot, at his will, depose his duly designated successor. Only if there is sufficient legal cause (an impeachable offense in modern constitutional terminology) can the electors depose the incumbent caliph, or his designated successor. To permit the electors to dismiss the caliph, or the caliph to dismiss his successor, at will, would undermine the right of the Muslim community to stability in the public order. (al-Māwardī n.d., 12).

Third, contract is the exclusive means by which any political authority can come into existence. Not only is the initial act of the selection of a ruler contractual, all appointments of inferior public officials are also contractual. While the contract of the caliphate is described as a bilateral one pursuant to

2 Al-Māwardī explains that "everyone in the community is obliged" ('alā kâffat al-umma) to participate in the contract that establishes the state.

3 The term "wali al-'ahd" is also significant insofar as it affirms the fiduciary character of the caliph's office. The term 'ahd indicates an undertaking, and in this context, it means that what is being delegated from the incumbent caliph to his designated successor is a solemn undertaking for the benefit of the Muslim community, not something for the caliph's personal benefit. 
which the community offers the caliphate to the successful candidate, who accepts the offer, it also necessitates the existence of an omnilateral contract among individual Muslims themselves to the effect that they will, upon establishing this public order, cease to enforce the law themselves. The obligation to appoint a caliph therefore necessarily entails the mutual agreement of the Muslims that they will not act unilaterally in pursuit of the public goals of the law. (al-Māwardī n.d., 17).

Accordingly, al-Māwardī's account of the contract of the caliphate includes a positive feature and a negative one. There is the positive delegation (tafwìd) to the caliph of the powers necessary to pursue the public good pursuant to the terms of the contract. Just as important, however, individual Muslims divest themselves of any claim they might have over the discharge of public interests. The public order, therefore, becomes the exclusive means through which the public good may be pursued:

Everyone in the community is obliged to delegate [administration] of common affairs to him, without any interference in his [jurisdiction] or opposition so that he can perform that which has been entrusted to him with respect to [attaining the general] welfare and [establishing the orderly] administration of [public] institutions. ${ }^{4}$

AL-MĀWARDī N.D., 17

By necessary implication, therefore, no one can exercise political authority over another without a valid appointment delegating authority to that person.

Fourth, the contract is of a fiduciary character, meaning, that the caliph and by extension, all lesser public officials, have no personal interest in the contract, but instead, serve exclusively the interests of those who appointed them. This is manifested in the operative verbs al-Māwardī chooses to describe the grant of authority to the caliph: he uses the verb wukkila - the passive voice for the verb used to appoint an agent—rather than, for example, mullikathe passive voice for the verb used to express the idea of transferring dominion over something, to express the fiduciary and representative character of the relationship between the caliph and the Muslim community.

Because the caliph is an agent, and not master, of the community, all the norms of the law of agency apply in determining whether his actions are legitimate. Islamic law defines the permissible ends of the Muslim community, and so actions of the caliph or lesser officials that violate Islamic law are outside

4 'alā kâffat al-umma tafwị̀ al-umūr al-'āmma ilayhi min ghayr iftiyāt 'alayhi wa lā mu'āraḍa li-yaqūma bi-mā wukkila ilayhi min wujūh al-mașālị̣ wa tadbīr al-a'māl. 
the terms of the contract, and therefore legally void, just as the actions of a private agent that go beyond the terms of the agreement with his principal are void. Because an agent can only be appointed to perform lawful acts, the Muslim community, in its capacity as principal, lacks the authority to appoint an agent to perform illegal acts. It cannot, therefore, ever be deemed to authorize wanton acts of criminality. Accordingly, "the people" in this conception cannot desire to commit acts of oppression, or if they do so in fact, the agent is not allowed to act on such an instruction because it is illegal. The ideal of agency therefore places inherent moral limits on how political power can be used: it can only be used for ends that are lawful and reasonably calculated to be beneficial to the public as determined from the internal perspective of Islamic law.

But the ideal of agency does more than limit the power of the state: it also authorizes the state to act in furtherance of the common good, even if it means compelling those under its jurisdiction in circumstances where they would not otherwise be bound. A simple example is the defendant's obligation to appear before a judge. Such an obligation is not manifested in revelation except in the abstract sense that Muslims must establish justice, but nothing in revelation identifies who is, in fact, a judge such that one has a moral obligation to appear before him or her. There can only be a moral duty to appear before a judge as a defendant if we can identify who is, from a normative perspective, a judge. The Sunni theory of the caliphate provides an answer to this question by saying that a person becomes a judge only if the Muslim community, acting through the caliph, or a lesser official having powers delegated to him from the caliph, has appointed that person a judge. A defendant has a moral obligation to appear before a judge because he himself, in a morally meaningful fashion, has appointed that person to act as judge, and has already authorized him to rule on contested issues of law in order to vindicate the common moral obligation to discharge justice in accordance with Islamic ideals. This theory of judicial legitimacy is made explicitly by the great Ḥanafĩ jurist Abū Bakr al-Kasānī. He explains that the judge is not appointed pursuant to the personal authority of the caliph, but rather by virtue of the authority of the Muslim community (wilāyat al-muslimin), and therefore his authority is derivative of theirs, and not the caliph. The caliph is merely their agent $(\operatorname{ras} \bar{u} l)$, with the effective appointing power, and dismissing power, in each case, being the Muslim community. The caliph has such powers because possession of that power, and its appropriate exercise, is crucial to their well-being. Accordingly, the actions of the caliph only appear to be his personal actions. In reality, they are the actions of the Muslim community itself. (al-Kasānī 1986, 7:16). 
The basis of obedience to the caliph's commands is neither his person, nor any special knowledge he might have of God's command; rather, obedience is owed to the caliph solely by virtue of the logic of the principal-agent relationship. The Sunni theory of the caliphate therefore provides a theological basis for self-government, by which I mean the creation of a system of morallybinding, human legislation that finds its origin in the immediate exercise of the Muslim community's will, not in the personal will of either the ruler, or the divine lawgiver. Having established that the Sunnī normative political ideal is derived from the principal-agent relationship, I now turn to the second part of this paper, the practical implications of this theory for political legitimacy in the Muslim world.

Vindicating the Sunnī Ideal of Self-Government

The most important means to vindicate the Sunnī ideal of self-government as articulated in the ideal theory of the caliphate is the notion of accountability. After all, if the caliph, as well as all other public officials are agents, it should follow that the principal, i.e., the Muslim community, has the inalienable right to hold its agents accountable for their actions. But what does accountability mean in this context?

Muslim jurists identify two kinds of agency relationships. In the first, known as an unrestricted agency (wikäla muțlaqa), the principal has essentially delegated to the principal the maximum amount of discretion conceivable, with the result that the agent can perform any action that the principal could have done for himself, limited only by the legality of the action, and whether the agent action furthered the principal's interest. Because an agent is required to pursue actions that benefit the principal, even in an unqualified agency agreement, the agent may not act in a manner contrary to the principal's interest, e.g., give away his property without fair consideration, without the principal's consent. (See al-Dardīr n.d., 3:508). At the same time, however, the principal, if he or she is dissatisfied with how the agent is exercising the powers delegated to him, is free to dismiss his agent at will. The second case is known as a restricted agency (wikäla muqayyada), because the principal has limited the agent's authority to specific ends set out in the agency agreement. In this latter case, the principal can hold the agent accountable not only for acting in a manner contrary to the principal's well-being, or for violating the law, but also for violating the limitations included in the agency contract. As an agency contract becomes more and more qualified, however, and limited in its scope, it is also more likely to be the case that the principal agrees to limit his otherwise 
unqualified power to dismiss the agent in the absence of some legal cause justifying dismissal, for example, in the absence of proof that the agent acted unlawfully, or that the agent violated specific terms of the agency agreement. Indeed, when an agency relationship is coupled with an interest of another party, including, the agent herself, the principal loses his right to dismiss the agent at will because it would threaten the third party's legitimate interest in the continued existence of the agency relationship. (al-Ḥațāa 1992, 187).

It is often the case then that whenever a principal wishes to hold an agent accountable, the principal will need to be able to resort to a court of law to do so effectively, whether or not the agency is restricted. But there is an important difference in the two kinds of agency agreements with respect to a court's ability to enforce the terms of the agreement: to the extent an agency contract is unrestricted, the court will only be able to discipline the agent if it can conclude that the agent used his powers in a manner that was not consistent with the principal's best interests. Other than cases of clear self-dealing, however, the court will generally give the agent the benefit of the doubt, by requiring the principal to prove conclusively that the agent knew that the challenged conduct was not in the principal's best interest at the time he undertook the action, a standard that is very difficult to meet. ${ }^{5}$ In a restricted agency relationship, by contrast, the principal need only show that the agent violated a term of the agency relationship to hold him liable.

One can speak of a trade-off that principals and agents face in coming to an agreement: to the extent that the agent is given broad discretion to act on behalf of the principal, it is likely that the principal will demand broad termination rights, while conversely, to the extent that the principal demands express limitations on the agent's authority, the agent is likely to seek restrictions on the right of the principal to dismiss him in the absence of a clear breach of the contract. Al-Māwardī's contract of the caliphate, although it is a restricted agency insofar as it only grants the caliph authority over public affairs (al-umūr al-ämma), nevertheless granted the caliph and other public officials vast discretion in determining the content of the public good, limited only by the requirement to avoid illegality-hence the legal principle "no obedience in sin (lā țāata li-makhlūq fì mașiyat al-khāliq)" - and the duty to pursue the best interests of the community. The Arabic term is qä idat al-așlah or qāidat al-ahsan. This principle is simply a manifestation of the fiduciary duty that applies to public officials insofar as their offices impose

5 This is reflected in the Islamic legal principal that a trustee is given the benefit of the doubt (al-amin musaddaq). Accordingly, in the ordinary case, the principal would have to prove that the agent acted wrongfully, not that the agent would have to prove that she acted rightfully. 
upon them a fiduciary duty toward the public. (See al-Qarāfì n.d., 4:39; Ahmad b. Muhammad Makkī 1985, 1:369; al-Suyūṭi 1990, 121). ${ }^{6}$ In these circumstances theory would predict that the jurists would have established for the Muslim community a strong right to dismiss public officials whom they believed to be acting in a fashion that was contrary to their interests, even if their actions were not obviously illegal. Yet, that was not the case. Al-Māwardī, for example, makes it clear that the caliph can only be deposed if he commits an illegal act, not simply for a display of incompetence. On the other hand, jurists did seem to expect that the caliph, in his capacity as head of state, would act decisively to dismiss officials who were incompetent, even if they were not criminal or corrupt. (al-Qarāfì n.d., 4:39).

How can we explain the absence of a formal system of caliphal accountability in Sunnī law? There is probably no single explanation, but one can reasonably propose several reasons, including: the relative weakness of even the strongest pre-nineteenth century Muslim states, a fact that made attempts to hold current rulers accountable to the public a risky venture at best; the general alignment between the interests of the public and those of the rulers, such that an incompetent ruler was likely to be replaced relatively quickly by a challenger; and, finally, the relative laxity by which Islamic law treated rebels always made rebellion against overbearing or incompetent government officials a real threat, something that no doubt exercised a very real, even if only informal, method of holding the ruler accountable for his actions. Whatever the explanation, it is indisputable that in the modern era, where the state is reasonably expected to deliver a host of public goods that goes well beyond the most ambitious political agenda of any pre-modern Muslim ruler, the informal means that existed prior to the 19th century to hold rulers accountable in the Muslim world are insufficient to do so now: both the risks and costs of incompetence, to say nothing of corruption and bad faith, are far too great in the modern period to tolerate the absence of real-time, effective means of accountability.

This gives rise to the Islamic justification for elections and democratic choice of rulers: the principal, i.e., "the people," must have an effective means of holding its representatives accountable for their actions in a fashion that is consistent with the public's right to a peaceful and stable public order. Recall,

6 Al-Q̨arāfi: "kullu man waliya wilāyat al-khilāfa fa-mā dūnahā ilā al-wașiyya lā yahillu lahu an yatașarrafa illā bi-jalb mașlaḥa wa dar' mafsada ... fa-yakūn al-ảimma wa'l-wulāt ma'zūlìna 'ammā laysa fìhi badhl al-juhd wa'l-marjuh abadan laysa bil-ahsan"; al-Makkī: "idhā kāna fi'l al-imām mabniyyan 'alā al-mașlaḥ fìmā yata'allaq bi'l-umūr al-āmma lam yanfudh amruhu shar'an illā idhā wafaqahu fa-in khalafahu lam yanfudh"; and, al-Suyūți: "al-qā'ida al-khāmisa tașarruf al-imām 'alà al-ra'iyya manūṭ bi'l-mașlahạ". 
that in Islamic law, a principal's right to dismiss his agent lapses if the agency relationship is coupled with the interest of a third-party. Here, regular elections provides the solution: the public can hold their representatives accountable while respecting the rights of third-parties to the maintenance of a stable and peaceful public order.

Some scholars have voiced objections to establishing public systems of accountability on the theory that it contradicts the Islamic principle of concealing the faults of others (satr) in favor of advising them in private, where it is asserted that they are more likely to accept correction. (See, for example, Abū al-Kāsn.d.). Such a position confuses the right of privacy that people enjoy as private persons, with the obligations that they incur when they agree to assume a public position. Thorough and honest evaluation of a public official's performance is not a matter of the agent's private honor and reputation, but rather is a matter of a duty owed to those who appointed him. Similar arguments were sometimes raised in the early centuries of Islam against the science of hadith criticism insofar as scholars' criticism of hadith reporters often raised doubts about the reporters' trustworthiness. Nevertheless, it was quickly recognized that the integrity of Islam depended upon the ability of Muslims to distinguish between reliable historical transmissions and unreliable ones, and so this objection was rightly overcome. (See al-Naysābūrī 2001, 115-117).

The same may be said with respect to information regarding the trustworthiness and competence of public officials: the great Andalusian jurist, al-Shātibi, for example, noted that corruption in public offices threatens the very foundations of Islam, as the integrity of public offices is the first principle of justice and is common to all humanity. (al-Shāțibī n.d., 2:177-78.) Accordingly, even if one must be concerned about the reputation of public officials, their interest in a good reputation for honesty and competency cannot serve as grounds for preventing public measures to hold them accountable for their actions. Otherwise, as Shāțibì suggests, the very foundations of Islam itself would be threatened as corruption would undermine all public life. Assuming a conflict between the private good of individual public officials in maintaining their reputations, and the universal public good in maintaining the integrity of public life, basic principles of Islamic jurisprudence require vindication of the universal good (al-mașlaha al-kulliyya) over the particular good of the individual public officials (al-mașlaha al-juz'iyya).

While accountability of public officials before the law is crucial for creating and sustaining the legitimacy of the public order by restraining them from violating the law, it does not, on its own, establish an effective system of selfgovernment under positive law. Accountability of public officials in a different sense is required in order to make positive law effective. This requires the 
establishment of mechanisms that ensure that public officials reasonably take into account the wishes of the principal when they make positive law in furtherance of the public good.

As noted briefly in previous section, Sunnì jurists recognized that public officials had the authority to promulgate morally binding rules in circumstances where revealed law, on its own, could not justify such obligations. The normative basis for such an obligation derived from the principal-agent relationship. Legally speaking the actions of an agent are the actions of the principal. From a practical perspective, however, a principal is likely to repudiate the actions of her agent if she believes the agent failed to take her views into account before acting, especially in circumstances where the agent could have easily consulted the principal. The ideal of the principal-agent relationship is best manifested when the agent acts precisely in the fashion that the principal would have wished her to act, had it been possible for the principal's wishes to be known. That is precisely the logic found in the historical rules regarding the role of a guardian in arranging a woman's marriage: when she is a minor, she need not be consulted because her opinion is legally irrelevant, but when she reaches full adulthood, only her express consent to a marriage is deemed acceptable, with even a contract which she wishes to ratify ex post being invalid if she takes more than three days to do so after it was contracted without her express consent. (See al-Dardīr n.d., 2:68). ${ }^{7}$

Insofar as public officials in Sunnī constitutional thought are authorized to make positive law to further the public interest, it follows that they must consult with the public to the extent reasonably practicable before making such laws. This obligation is not only implicit in the nature of the principalagent relationship that constitutes the public order in Sunni political thought, the Quran expressly praises the practice of mutual deliberation as a means to resolve disputed questions of the common good. (al-Shürā, 42:38). It even commanded the Prophet Muhammad, despite his status as a prophet, to consult his companions before resolving any matter of public concern. (Ál Imrān, 3:159).

Participation of the public in law making is likely to make positive law more effective for several reasons. First, the formal relationship of agency that undergirds the normative legitimacy of the state risks becoming an empty shell if

7 This issue is known as al-muftāt 'alayhā, i.e., a woman whose autonomy has been invaded, and refers to a situation where a guardian of an adult woman purports to contract a marriage on her behalf, and then presents it to her, after the fact, for her ratification. According to Mālikī fiqh, if she does not promptly ratify that marriage contract, i.e., within three days after it was contracted, the contract automatically is void, even should she wish to ratify it beyond the three day period stipulated by the jurists. 
public officials do not, in fact, take on the appearance, as well as the reality, of acting in the manner of an agent. Second, in order to craft rules that will effectively achieve the public interest, public officials must consult with the public in order to obtain the information necessary to determine where the public interest reasonably lies. Third, even a wise, omniscient lawgiver will fail if the citizens do not obey the wise laws he has formulated for them. A wise lawgiver, therefore, will strive to persuade the subjects of the law that the laws are nothing other than what, upon due reflection, they would legislate for themselves if given the opportunity. One sees this dynamic at play even in the rhetoric of the jurists with respect to how the public should be instructed in the rules of divine law. Al-Shātibì, for example, argued that it was the practice of the divine lawgiver to introduce the rules of divine law gradually, in accordance with the people's reasonable needs, so that they could adopt them over time through a gradual process of internalization. (al-Shāțibī n.d., 93-94.) Such a legislative strategy is required if, as Shâțibi argued, the divine lawgiver's intent that the law's subjects adhere to it freely rather than out of compulsion is to be realized. (al-Shāțibī n.d., 168.) The same principle applies a fortiori for a human lawgiver whose authority derives from the people: only by convincing them that the laws which he proposes for them are, in fact, what they would choose for themselves is there a reasonable prospect that they will comply with those rules. When laws, even wise laws are imposed on the people without a reasonable attempt to involve the people in making those laws, or understanding why they are necessary, there is a strong risk that they will refuse to abide by such laws entirely, at least in the absence of overpowering force.

Fourth, wise laws require someone or some group willing to defend the integrity of the law in the event that such laws are broken, whether by public officials or by ordinary citizens. This is analogous in the domain of revealed law to the concept of "commanding the good and forbidding the evil (alamr bil-ma'rüf wa'l-nahy 'an al-munkar)." It is unlikely that the people will be motivated to defend the integrity of positive laws, however, unless they feel that those laws are their own. The formal model of agency described by Sunni jurists provides a reason to think that the people would want to defend the integrity of the law, but only if the formal model of a principal-agent relationship is made practically effective by cultivating the public's active participationinthelaw-makingprocess. Onlywhenthepeople'spotentialasaselfgoverning principal is actualized through public officials who strive to represent them diligently and effectively, including, by making themselves meaningfully accountable to the people for their actions, can we speak of a legal order that is legitimate in the sense that people obey it freely, and not simply because they fear the ruler's threats. 
This essay was motivated by a desire to articulate an Islamic theory of legitimate politics (shar'iyya siyāsiyya) that goes beyond traditional conceptions of legitimate exercises of power (siyāsa shariyya). If Muslims thought they could be indifferent to questions of political legitimacy, the events of the Arab Spring have made clear that even if they attempt to forget politics, politics will not forget them. This essay shows that the Islamic tradition provides the Muslim world with rich resources for developing effective institutions of selfgovernment that could be consistent with adherence to divine law. I hope that all those concerned with the future of the region, and its peoples, reflect deeply on the political values that the Sunni tradition affords them in imagining a democratic, peaceful and prosperous future for everyone in the region.

\section{Bibliography}

Abū al-Kās, Rāìd 'Alī. n.d. al-Nașịha li-Wulāt al-Umūr. Kayfiyyatuhā wa Șuwaruhā wa Aqwāl al-Salaf fìhā. Link: https://www.sahab.net/forums/index.php?app=forums\& module=forums\&controller=topic\&id=126193, accessed 17 Nov. 2017.

Aḥmad b. Muḥammad Makkī, Shihāb al-Dīn. 1985. Ghamz 'Uyūn al-Baṣā̉ir fì Sharh alAshbāh wa'l-Nazā̄ir. 4 volumes. Beirut: Dār al-Kutub al-Tlmiyya.

Crone, Patricia. 2005. “The Kharijites." In God's Rule: Government and Islam, 54-64. New York: Columbia University Press.

al-Dardīr, Abū al-Barakāt Aḥmad b. Muḥammad b. Aḥmad. n.d. al-Sharḥ al-Ṣaghīr. Edited by Muștafā Kamāl Wașfì. 4 vols. Cairo: Dār al-Macārif.

Fadel, Mohammed. 2017. "Islamic Law Reform: Between Reinterpretation and Democracy." Yearbook of Islamic and Middle Eastern Law Online 18, no. 1: 44-90. http://booksandjournals.brillonline.com/content/journals/10.1163/22112987_ 01801005.

Fadel, Mohammad. 2014. "State and Shariaa." In The Ashgate Research Companion to Islamic Law, edited by Peri Bearman and Rudolph Peters, 93-107. Surrey: Ashgate.

Gaiser, Adam. 2010. Muslims, Scholars, Soldiers: the Origin and Elaboration of the Ibadi Imamate Traditions. New York: Oxford University Press.

al-Ghazālī, Abū Ḥāmid Muḥammad b. Muḥammad. 1986. Ihyyā' 'Ulūm al-Dīn. vol 1. Beirut: Dār al-Kutub al-'Tlmiyya.

al-Ḥaț̣āb, Muḥammad b. Muḥammad b. 'Abd al-Raḥmān. 1992. Mawāhib al-Jalīl liSharh Mukhtașar Khalïl, 3rd ed. vol 5. Beirut: Dār al-Fikr.

Ibn 'Abd al-Salām, 'Izz al-Dīn. n.d. Qawā'id al-Ahkām fì Maṣālih al-Anām. 2 vols. Beirut: Dāral-Ma'rifa. 


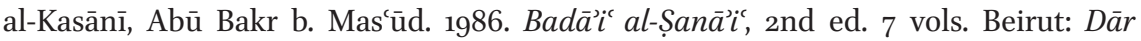
al-Kutub al-Tlmiyya.

al-Māwardī, Abū al-Ḥasan 'Alī b. Muḥammad b. Habīb. n.d. al-Aḥkām al-Sulțāniyya. Beirut: Dār al-Kutub al-'Tlmiyya.

al-Naysābūrī, Al-Ḥākim. 2001. al-Madkhal ilā Márifat Kitāa al-Iklīl. Edited by Mưtazz al-Khațīb. Damascus: Maktabat Dār al-Fayḥẳ.

al-Qarāfì, Shihāb al-Dīn Aḥmad b. Idrīs. n.d. al-Furūq. 4 vols. Beirut: 'Ālam al-Kutub.

al-Shāțibī, Abū Ishāa Ibrāhīm b. Mūsā.n.d. Al-Muwāfaqāt. Edited by 'Abd Allāh Darrāz. 4 vols. Beirut: Dār al-Márifa.

al-Shirbīnī, Shams al-Dīn Muḥammad b. Muḥammad. 1994. Mughnī al-Muḥtāj. 6 vols.

Beirut: Dār al-Kutub al-Tlmiyya.

al-Suyūțī, Jalāl al-Dīn. 1990. al-Ashbāh wa'l-Nazā̇ir. Beirut: Dār al-Kutub al- Tlmiyya.

Weiss, Bernard. 1990. "Exotericism and Objective in Islamic Jurisprudence." In Islamic Law and Jurisprudence, 53-71. Seattle: University of Washington Press.

Yusuf, Hamza. 2007. The Creed of Imam al-Tahawi. Translated by Hamza Yusuf. Berkeley: Zaytuna Institute.

Ziadeh, Farhat. 1994. "Integrity ('Adālah) in Classical Islamic Law," In Islamic Law and Jurisprudence: Studies in Honor of Farhat J. Ziadeh, edited by Nicholas Heer, 73-93. Seattle: University of Washington Press. 